\title{
Silvicultural and Dendroclimatic Analysis of Artificial Pine Phytocenoses Exposed to Recreational Digression in a Suburban Area of Voronezh
}

\author{
Sergey M. Matveev*, \\ Alexey V. Mironenko and Darya A. Timashchuk \\ Voronezh State Academy of Forestry Engineering \\ 8 Timiryazeva Str., Voronezh, 394087, Russia
}

Received 08.07.2015, received in revised form 24.08.2015, accepted 04.10.2015

The paper presents the results of silvicultural research of phytocenosis components and dendrochronologocal and dendroclimatic analyses of radial growth of pine and limiting factors in 50-70 year old stands of Scots pine in different stages of recreational digression, which grow in a suburban area of Voronezh.

Weighted average of the category of the state of the examined tree stands increases from I, 7 to III, 1 with increasing the stage of digression from I to IV. On III-IV and IV stages of digression tree stands are classified as "very weak." With increasing recreational load the projective ground cover of herbaceous plants and their aboveground phytomass decreases, the share of participation and diversity varies (weeds and meadow grass appear).

The tree stands which exposed to intensive recreational impact significantly more affected by drought in 2010. In 2012 - 2013 years the average radial growth of trees increased in stands which are in I and II stages of digression, while in stands belong to III and IV stages it continues to decline. So far, the desiccation of particular trees continues in all artificial pine stands regardless of the stage of digression. The coefficients of variation of growth sharply increase to a maximum value (>60\%) in the years after the severe drought, and after two-year especially severe drought (1971-1972 and 2009-2010) the increase of the coefficient of variation is also observed during two or even three years (1973-1974 and 2011-2013).

It is clear that Stage IV of the digression is a transition of the tree stand to irreversible phase of deterioration.

Keywords: Scots pine, Pinus sylvestris L., recreational impact, stage of digression, the state stands, radial increment, the coefficient of variation, dendroclimatic analysis, precipitation, drought.

DOI: $10.17516 / 1997-1389-2015-8-4-410-425$.

(c) Siberian Federal University. All rights reserved

* Corresponding author E-mail address: lisovod@bk.ru 


\section{Лесоводственный и дендроклиматический анализ \\ искусственных сосновых фитоценозов, \\ подверженных рекреационной дигрессии \\ в пригородной зоне г. Воронежа}

С.М. Матвеев,

А.В. Мироненко, Д.А. Тимащук

Воронежская государственная лесотехническая академия Россия, 394087, Воронеж, ул. Тимирязева, 8

Представлены результаты лесоводственного исследования компонентов фитоценоза, а также дендрохронологического и дендроклиматического анализов радиального прироста сосны и лимитирующих факторов, проведенных в 50-70-летних насаждениях сосны обыкновенной в пригородной зоне г. Воронежа, находящихся на разных стадиях рекреационной дигрессии.

Средневзвешенное значение категории состояния обследованных древостоев возрастает om I,7 до III,1 при изменении стадии дигрессии от I к IV. На III-IV и IV стадиях дигрессии древостои относятся к категории «сильно ослабленные». По мере увеличения рекреационной нагрузки снижается проективное покрытие почвы травянистыми растениями и их надземная фитомасса, изменяются долевое участие и видовое разнообразие (появляются сорные и луговые травы).

Древостои, подверженные интенсивному рекреационному воздействию, значительно сильнее пострадали от засухи 2010 г. В 2012-2013 гг. средний радиальный прирост древесины в насаждениях, находящихся на I и II стадиях дигрессии, увеличился, в то время как в древостоях на III и IV стадиях дигрессии он продолжает снижаться. До настоящего времени по-прежнему усыхают отдельные деревья во всех искусственных древостоях сосны независимо от стадии дигрессии. Резко увеличиваются до максимальных значений (>60\%) коэффициенты изменчивости прироста в годы после сильных засух, причем после двухлетних особенно сильных засух (1971-1972 и 2009-2010 г2.) повышение коэффициента изменчивости также наблюдается в течение двух и даже трех лет (1973-1974 и 2011-2013 гг.).

Очевидно, что IV стадия дигрессии является переходом древостоя к необратимой фазе ухудшения состояния.

Ключевые слова: сосна обыкновенная, Pinus sylvestris L., рекреаџионное воздействие, стадия дигрессии, состояние древостоев, радиальный прирост, коэффициент изменчивости, дендроклиматический анализ, осадки, засуха.

\section{Введение}

Сосновые насаждения Сомовского лесничества Воронежской области являются частью лесного массива Усманского бора. Сосна образует высокопродуктивные древостои на песчаных и супесчаных почвах, расположенных преимущественно по левобережью рек Воронеж и Усмань (Вересин, 1971). В послед- 
ние десятилетия, в связи с интенсивным использованием жителями г. Воронежа и близлежащих посёлков пригородных территорий для отдыха, сосновые насаждения подвергаются интенсивному рекреационному воздействию (Никитченко, Миленин, 2012; Тимащук, Матвеев, 2012).

Рекреационная нарушенность леса определяется комплексом признаков, в числе которых: видовой состав и структура растительности, вытоптанность почвы, темп радиального прироста у деревьев и др. Одновременно следует иметь в виду замусоренность (загрязненность) насаждения и санитарное состояние древостоя. При проведении комплексной оценки лесов рекреационного назначения необходимо учитывать не только их качество в настоящее время, но и динамику развития насаждений (Рысин, Рысин, 2008).

Рекреационное воздействие в большей или меньшей степени затрагивает все структурные элементы фитоценозов, и для оценки глубины этих изменений необходимо использование как лесоводственного, так и дендроклиматического методов анализа.

Исследователи проявляют устойчивый интерес к древесным растениям как индикаторам изменений природных условий. Это можно проследить начиная с классических работ Ф.Н. Шведова (1892), А.Э. Дугласа (1919), М.П. Скрябина (1946), С.И. Костина (1965), С.Г. Шиятова (1973), Т.Т. Битвинскаса (1974), Б.А. Колчина, Н.Б. Черных (1977) и др. Изучение радиального прироста в качестве одного из методов фитоиндикации антропогенного воздействия на лесные экосистемы стали использовать сравнительно недавно (Ловелиус, 1979; Николаевский, 1983; Таранков, 1993 и др.).

Дендроклиматический анализ, т.е. метод анализа временных рядов или серий календарно продатированных годичных слоев дере- вьев (Ваганов и др., 1996), позволяет получить ответ на большой спектр вопросов, связанных с динамикой леса, реконструкцией и прогнозированием природно-климатических изменений.

Отрицательное влияние рекреационного лесопользования на рост деревьев наиболее выражено в нарушении цикличности радиального прироста. При интенсивности нагрузки, характерной для IV стадии дигрессии, происходит некоторое снижение прироста и нарушение цикличности. При максимальной нагрузке (V стадия дигрессии) резко повышается амплитуда колебаний и значительно нарушается цикличность прироста (Матвеев, 2005).

В данной работе представлены результаты лесоводственного исследования компонентов фитоценоза, а также дендрохронологического и дендроклиматического анализов радиального прироста сосны и лимитирующих факторов, проведенных в 50-70-летних насаждениях сосны обыкновенной, находящихся на разных стадиях рекреационной дигрессии.

\section{Материалы и методы}

Полевые исследования проведены в сосновых фитоценозах пригородной зоны г. Воронежа (Сомовское лесничество): урочище «Боровое» $\left(51^{\circ} 65^{\prime}\right.$ с.ш., 39³2' в.д.) и урочище «Маклок» (51²7' с.ш., 39³4' в.д.) летом 2013 г. (рис. 1).

Пробные площади заложены в чистых по составу искусственных древостоях сосны обыкновенной (с небольшой примесью березы). В урочище «Маклок» были заложены три пробные площади (ПП № 1-3), которые находятся на разном расстоянии от пос. Маклок и оз. Маклок, в урочище «Боровое» - две ПП (№ 4 и 5), находящиеся на разном расстоянии от пляжа на р. Усманка и пос. Боровое. В связи 


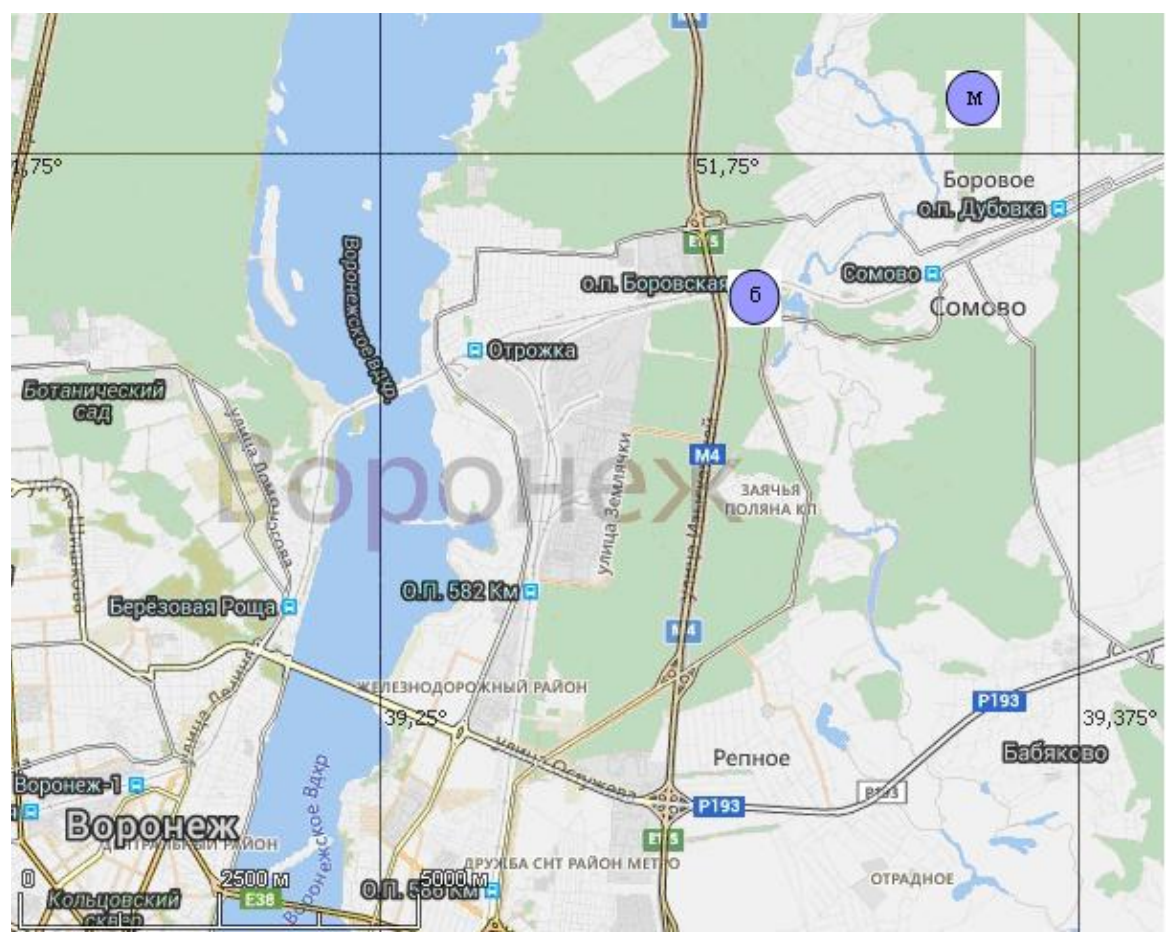

Рис. 1. Схема района исследований. Пригородные леса г. Воронежа. Места закладки пробных площадей: (6) - урочище Боровое, (M -урочище Маклок

с разной удаленностью от источников рекреационного воздействия растительность этих ПП находится на разных стадиях рекреационной дигрессии (табл. 1). Размер пробных площадей 0,5 га $(100$ м × 50 м). В урочище «Боровое» возраст древостоя 50 лет, в урочище «Маклок» - 64-70 лет. Все пробные площади заложены в свежих суборях (тип лесорастительных условий $\mathrm{B}_{2}$ ), тип леса - сосняк разнотравный (Ссрт).

На пробных площадях проведены исследования древостоя, подлеска, подроста, живого напочвенного покрова по лесоводственнотаксационным показателям. Таксационные характеристики древостоев сходны и позволяют проводить сравнительный анализ по фактору воздействия: рекреационной дигрессии (табл. 1).

Жизненное состояние древостоев оценивали по шкале категорий состояния леса
(Санитарные правила в лесах Российской Федерации, 1998).

Для дендрохронологического анализа осенью 2013 г. на каждой пробной площади отобрано по 12 образцов (кернов) древесины на высоте 1,3 м. Датировка и измерение ширины годичных колец проведены на измерительном комплексе LINTAB-6 с использованием специализированного программного пакета TSAP-Win (версия профессиональная). Расчет относительных индексов прироста выполнен в программе TREND (Мироненко, Матвеев, 2012). По данным измерений строились графики радиального прироста, которые использовались для точной абсолютной датировки годичных колец при помощи метода перекрестной датировки (Douglass, 1919).

Основные статистические характеристики дендрохронологических рядов рассчитаны по ширине годичных колец для каждой проб- 
Таблица 1. Таксационная характеристика древостоев сосны обыкновенной на пробных площадях Сомовского лесничества

\begin{tabular}{|c|c|c|c|c|c|c|c|c|c|c|}
\hline$\frac{\text { Пробная площадь № }}{\text { Урочище }}$ & 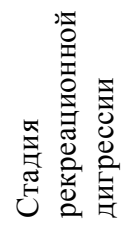 & 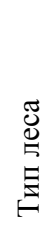 & $\stackrel{\lambda}{\stackrel{G}{G}}$ & $\begin{array}{l}\stackrel{9}{*} \\
\tilde{J} \\
0\end{array}$ & 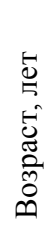 & 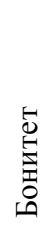 & $\underline{\Xi^{\hat{O}}}$ & $\begin{array}{c}\sum_{0}^{\Sigma} \\
0^{\hat{U}}\end{array}$ & 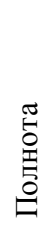 & 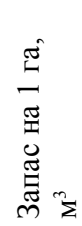 \\
\hline
\end{tabular}



ной площади (по стадиям рекреационной дигрессии) в программе STADIA (табл. 2).

По каждой пробной площади с помощью пакета программ TSAP-Win рассчитаны коэффициенты сходства ширины годичных колец каждого образца со средним (GLK - коэффициент синхронности, СС - коэффициент корреляции, SNR - соотношение сигнал/шум).
Для оценки изменчивости индексов прироста рассчитаны погодичные значения коэффициента изменчивости дендрохронологических образцов, стандартного отклонения, вероятной ошибки.

Числа Вольфа получены с сайта открытого доступа SIDC (Solar Influences Data analysis Center (2013)). 
Климатические показатели рассчитаны нами по данным наблюдений метеостанции № 34123 «Воронеж», 51 40’ с.ш., 39 13’ в.д., высота над уровнем моря 149 м (Погода и климат ... (2013)).

Для объективного упорядочения анализируемых показателей в сравнительно однородные группы по календарным годам дендрошкалы деревьев и хронологии лимитирующих факторов подвергли математической обработке при помощи кластерного анализа (метод Варда) в программе STADIA.

\section{Результаты и обсуждение}

Лесоводственный анализ компонентов фитоценоза показал, что средневзвешенное значение категории состояния древостоев (табл. 3) возрастает при переходе от I к IV стадии дигрессии и изменяется от I,7 до III,1. На III-IV и IV стадиях дигрессии средневзвешенное значение категории состояния древостоев составляет II,9 и III,1, т.е. превышает II,5, соответственно, древостои на этих стадиях относятся к категории «сильно ослабленные».

Видовой состав подлеска на пробных площадях сходный и характерен для раз- нотравных типов леса лесостепи, но на площадях с большей рекреационной нагрузкой преобладает рябина обыкновенная, акация желтая, жимолость татарская. На пробных площадях с меньшей рекреационной нагрузкой больше бересклета бородавчатого, лещины обыкновенной, появляется также бузина красная, клён полевой, липа мелколистная (табл. 4).

По мере уменьшения рекреационной нагрузки увеличивается количество подроста и его высота, т.е. улучшается возобновление.

Учет напочвенного покрова показал, что с возрастанием рекреационной нагрузки уменьшается степень проективного покрытия почвы травянистыми растениями и их надземная фитомасса, изменяется долевое участие и видовое разнообразие. На IV стадии дигрессии доля лесных видов значительно уменьшается, некоторые виды исчезают (Convallaria majalis L., Fragaria vesca L., Athyrium filixfemina (L.) Roth). Появляются новые луговые и сорные виды (Taraxacum officinale Wigg., Chelidonium majus L.).

Исследование кернов древесины сосны обыкновенной (возраст 50-70 лет) показало наличие в древостоях, испытывающих ре-

Таблица 3. Распределение деревьев сосны по категориям состояния древостоя: над чертой - шт/га, под чертой - \% от общего числа

\begin{tabular}{|c|c|c|c|c|c|c|c|c|c|}
\hline \multirow{2}{*}{$\begin{array}{l}\text { Номер } \\
\text { ПП }\end{array}$} & \multirow{2}{*}{$\begin{array}{c}\text { Стадия } \\
\text { дигрессии }\end{array}$} & \multirow{2}{*}{$\begin{array}{c}\text { Средневзвешенное } \\
\text { значение категории } \\
\text { состояния древостоя }\end{array}$} & \multicolumn{6}{|c|}{ Категории состояния древостоев } & \multirow{2}{*}{$\begin{array}{c}\text { Всего на } \\
\text { ПП }\end{array}$} \\
\hline & & & I & II & III & IV & V & VI & \\
\hline 3 & I & $\mathrm{I}, 7$ & $\frac{92}{49,5}$ & $\frac{55}{29,6}$ & $\frac{34}{18,3}$ & $\begin{array}{c}\underline{4} \\
2,2\end{array}$ & $\frac{1}{0,4}$ & - & $\frac{186}{100}$ \\
\hline 2 & II & II, 0 & $\frac{66}{39,2}$ & $\frac{48}{28,5}$ & $\frac{46}{27,3}$ & - & $\underline{6}$ & $\frac{2}{1,4}$ & $\frac{168}{100}$ \\
\hline 1 & II-III & II, 1 & $\underline{59}$ & $\underline{56}$ & $\frac{39}{22,9}$ & $\underline{9}$ & $\frac{5}{2,9}$ & $\frac{2}{1,3}$ & $\frac{170}{100}$ \\
\hline 4 & III-IV & II, 9 & $\frac{14}{8,2}$ & $\frac{46}{27,0}$ & $\frac{67}{39,4}$ & $\frac{27}{15,9}$ & $\frac{11}{6,5}$ & $\frac{5}{3,0}$ & $\frac{170}{100}$ \\
\hline 5 & IV & III, 1 & $\frac{13}{7,9}$ & $\frac{41}{24,8}$ & $\frac{58}{35,2}$ & $\frac{31}{18,8}$ & $\frac{13}{7,8}$ & $\frac{9}{5,5}$ & $\frac{165}{100}$ \\
\hline
\end{tabular}


Таблица 4. Состав и структура лесных фитоценозов, находящихся на разной стадии рекреационной дигрессии (I-IV)

\begin{tabular}{|c|c|c|c|c|c|}
\hline \multirow{2}{*}{ Биологический вид } & \multicolumn{5}{|c|}{ Стадия рекреационной дигрессии } \\
\hline & I & II & II-III & III-IV & IV \\
\hline \multicolumn{6}{|c|}{ Проективное покрытие напочвенного покрова, \% } \\
\hline Зеленые мхи (Bryidae Engl.) & 30 & 20 & 10 & 2 & 3 \\
\hline Одуванчик лекарственный (Taráxacum officinále Wigg.) & 17 & 20 & 30 & 23 & 50 \\
\hline Крапива двудомная (Urtíca dióica L.) & 14 & 18 & 25 & 5 & - \\
\hline Копытень европейский (Ásarum europaéum L.) & 12 & - & 2 & - & - \\
\hline Ландыш майский (Convallária majális L.) & 10 & 19 & 7 & - & - \\
\hline Земляника лесная (Fragária vésca L.) & 6 & 8 & - & - & - \\
\hline Вейник наземный (Calamagróstis epigéios (L.) Roth) & - & - & - & 10 & 20 \\
\hline Кочедыжник женский (Athýrium fílix-fémina L.) & 4 & - & - & - & - \\
\hline Ясменник пахучий (Aspérula odorata L.) & 2 & - & 2 & - & - \\
\hline Осока волосистая (Carex pilosa Scop.) & - & 10 & 20 & 10 & 7 \\
\hline Тысячелистник обыкновенный (Achilléa millefólium L.) & 2 & 5 & - & - & - \\
\hline Чистотел большой (Chelidónium május L.) & - & - & 4 & 50 & 20 \\
\hline Подорожник большой (Plantágo májor L.) & 3 & - & - & - & - \\
\hline \multicolumn{6}{|c|}{ Подлесок, шт/га } \\
\hline Рябина обыкновенная (Sórbus aucupária L.) & 240 & 320 & 240 & 640 & 160 \\
\hline Бересклет бородавчатый (Euonymus verrucosus Scop.) & 160 & 80 & 880 & - & - \\
\hline Липа мелколистная (Tilia cordata Ehrh.) & 160 & - & - & - & - \\
\hline Жимолость татарская (Lonícera tatárica L.) & 320 & 160 & 160 & 80 & 160 \\
\hline Лещина обыкновенная (Córylus avellána L.) & 80 & 660 & 80 & 160 & - \\
\hline Крушина ломкая (Frángula álnus Mill.) & 720 & 80 & - & 160 & - \\
\hline Бузина красная (Frángula álnus L.) & 320 & 80 & - & - & - \\
\hline Клен полевой (Ácer campéstre L.) & - & - & 160 & - & - \\
\hline Акация желтая (Caragána arboréscens L.) & - & - & 80 & 160 & 320 \\
\hline \multicolumn{6}{|c|}{ Подрост, шт/га } \\
\hline Сосна обыкновенная (Pinus sylvestris L.) & 4550 & 3500 & 1500 & - & - \\
\hline
\end{tabular}

креационное воздействие, деревьев со значительными отклонениями от установленных для региона за 100-летний период (Матвеев, 2006) дат календарных экстремумов. Доля таких деревьев в древостоях, находящихся на III - IV стадии рекреационной дигрессии, составляет порядка $20 \%$.

Вероятная ошибка определения среднего прироста на разных стадиях рекреационной дигрессии составляет от 12,6 до 16,3\%, т.е. несколько выше требуемого значения (10 \%) (табл. 5). Но при анализе достоверности данных измерений ширины годичного кольца (по 12 кернам) критерием Стьюдента (t) мы получили фактические значения $\left(\mathrm{t}_{\text {фак }}\right)$ за каждый календарный год, превышающие стандартное значение $\mathrm{t}_{\mathrm{c \tau}}=2,18$ для уровня вероятности 0,95 , т.е. среднее значение прироста определено достоверно.

Осредненные значения коэффициента синхронности радиального прироста практически на всех стадиях дигрессии сред- 
Таблица 5. Значения коэффициента изменчивости радиального прироста деревьев сосны по годам $(\mathrm{CV}, \%)$ за весь период роста и вероятная ошибка $\left(\mathrm{P}_{\mathrm{sr}}\right)$ определения среднего прироста деревьев, растущих в насаждениях, находящихся на разных стадиях рекреационной дигрессии

\begin{tabular}{cccccc}
\hline $\begin{array}{c}\text { Стадия } \\
\text { дигрессии }\end{array}$ & $\begin{array}{c}\text { Среднее } \\
\text { значение CV }\end{array}$ & $\begin{array}{c}\text { Диапазон } \\
\text { колебаний CV }\end{array}$ & CVmax / год & CVmax 2/ год & $\mathrm{P}_{\mathrm{sr}}$ \\
\hline I & 48,0 & $31,4-65,9$ & $65,9 / 2012$ & $63,2 / 2011$ & 14,6 \\
II & 41,5 & $23,7-90,8$ & $90,8 / 2011$ & $89,3 / 2012$ & 13,0 \\
II-III & 40,4 & $21,6-96,7$ & $96,7 / 2012$ & $96,6 / 2013$ & 12,6 \\
III-IV & 47,2 & $15,3-82,8$ & $82,8 / 2013$ & $63,7 / 2010$ & 14,6 \\
& & & $60,7 / 2012$ & \multirow{2}{*}{ IV } \\
\multirow{2}{*}{54,2} & $27,4-104,1$ & $104,1 / 2012$ & $86,4 / 2013$ & 16,3 \\
\hline
\end{tabular}

Примечание: $\mathrm{CVmax}$ - максимальные значения коэффициента изменчивости радиального прироста деревьев, CVmax 2 - значения коэффициента, следующие за максимальными.

Таблица 6. Средние значения коэффициента синхронности (GLK, \%), коэффициента корреляции (CC, \%), соотношение сигнал / шум (SNR) индивидуальных хронологий радиального прироста деревьев сосны, растущих в насаждениях, находящихся на разных стадиях рекреационной дигрессии

\begin{tabular}{|l|c|c|c|c|c|c|}
\hline $\begin{array}{c}\text { Район } \\
\text { исследований }\end{array}$ & № ПП & $\begin{array}{c}\text { Стадия } \\
\text { дигрессии }\end{array}$ & GLK, \% & $\begin{array}{c}\text { Уровень синхронности } \\
\text { (Шиятов, 1986) }\end{array}$ & CC, \% & SNR \\
\hline \multirow{2}{*}{$\begin{array}{l}\text { Урочище } \\
\text { «Маклок» }\end{array}$} & 3 & I & 70,0 & Средняя & 80,2 & 48 \\
\cline { 2 - 8 } & 2 & II & 72,4 & Средняя & 77,1 & 40 \\
\cline { 2 - 8 } & 1 & II-III & 76,6 & Средняя & 87,8 & 88 \\
\hline $\begin{array}{l}\text { Урочище } \\
\text { «Боровое» }\end{array}$ & 4 & III-IV & 76,8 & Средняя & 78,8 & 45 \\
\cline { 2 - 8 } & 5 & IV & 65,8 & Низкая & 80,5 & 51 \\
\hline
\end{tabular}

ние (68-78 \%) по шкале С.Г. Шиятова (1986) (табл. 6). Однако ряд деревьев показывает как высокое, так и очень низкое сходство, доля деревьев с низким сходством максимальна на IV стадии рекреационной дигрессии. Самый низкий коэффициент синхронности (44 \%), причем у двух деревьев, наблюдается на IV стадии рекреационной дигрессии. Осредненный коэффициент корреляции ширины годичных колец всех исследованных образцов (кернов) варьирует от 77,1 до 87,8 \%. Диапазон колебаний его значений по всем кернам составляет от 55 до $95 \%$, причем деревья с высокой синхронностью могут показать сравнительно низкий коэффициент корреляции, и, наоборот, высокий коэффициент корреляции может наблюдаться при низкой синхронности.
Значительный интерес представляет анализ изменчивости радиального прироста древостоев сосны рекреационной зоны г. Воронежа в годы с экстремальными климатическими условиями (в лесостепи это засухи) и последующие за ними.

А.В. Тимофеевым (2008) проведено графическое сопоставление дат сильных засух в пригородных лесах г. Самары (лесостепь Среднего Поволжья) с минимальными значениями абсолютного радиального прироста сосны обыкновенной. Выявлено меньшее отрицательное влияние засух в злаковых сосняках на вершинах дюнных всхолмлений, чем в сосняках травяных и разнотравных с примесью лиственных пород. Автор логично объясняет результат 
адаптивностью сосны в злаковых типах лесорастительных условий к большим повышениям температуры.

В работе И.Л. Вахниной (2011) отмечается, что повышение температуры воздуха (при лимитирующем факторе - количество осадков) во влажные периоды усиливает радиальный прирост сосны в зелёной зоне г. Читы, а в сухие годы - угнетает его.

По исследованиям Н.В. Рыгаловой (2014), использовавшей кластерный анализ, в условиях ленточных боров степной зоны Алтая кластеризация хронологий сосны в годы с недостаточным увлажнением (гидротермический коэффициент (ГТК) Селянинова отклоняется на 25 \% от нормы) идентична кластеризации за весь исследованный период, тогда как в годы с избыточным увлажнением группировка кластеров изменяется.

Проведенный нами анализ изменчивости радиального прироста сосны по календарным годам показал, что низкие коэффициенты изменчивости чаще наблюдаются в годы с экстремумами климатических условий (засухи) или, наоборот, в годы с очень благоприятными условиями.

Резко увеличиваются до максимальных значений (>60 \%) коэффициенты изменчивости в годы после сильных засух, после двухлетних особенно сильных засух (1971-1972 и 2009-2010 гг.) повышение коэффициента изменчивости также наблюдается в течение двух и даже трех лет (1973-1974 и 20112013 гг.).

В 2011-2013 гг. резко «взлетел» коэффициент изменчивости, причем в древостое ненарушенном (І стадия дигрессии) до 65,9 \%, а на II-IV стадиях - до 82,8-104,1\%. Ha IV стадии дигрессии среднее значение коэффициента изменчивости $(54,2 \%)$ и его амплитуда $(27,4$ - 104,1 \%) самые высокие (табл. 5).
Мы рассмотрели радиальный прирост всех образцов с момента последнего значительного максимума (2004 г.).

Сумма осадков за год перед жарой 2010 г. падала с 2004 по 2009 г., ниже среднемноголетних значений - с 2007 по 2009 г. В 2010 г. суммарное количество осадков увеличилось и превысило среднемноголетнее.

Количество осадков за теплый период (апрель-сентябрь) после максимума 2004 г. падало также до 2007 г., но в 2008 г. несколько увеличилось (что немедленно отразилось на радиальном приросте сосны) и резко упало (до 182 мм) в 2009 г., в 2010 г., как и по общей сумме, превысило среднемноголетнее. То есть 2009 г. был сухой (особенно вегетационный период), a 2010 г. - жаркий. В 2011 г. количество осадков вновь снизилось, но не так, как в 2009 г. (280 мм за теплый период), и особенно многоводными были 2012 и 2013 гг. В древостоях от I до II и III стадий дигрессии урочища «Маклок» как ширина годичного кольца, так и отдельно поздней древесины оставалась малой с 2010 по 2012 гг., несмотря на то что вегетационные периоды 20112012 гг. были благоприятными по климатическим условиям (теплыми и влажными). На стадиях дигрессии III-IV и IV урочища «Боровое» общая ширина годичного кольца не увеличилась и в 2013 г. практически у всех деревьев, т.е. из-за засухи 2010 г. продолжается усыхание части деревьев в древостоях, не пострадавших от пожаров (табл. 7). Особенно губительной засуха 2010 г. оказалась для деревьев, подверженных интенсивной рекреационной нагрузке, что является следствием как влияния рекреационной нагрузки, так и неспособности ослабленных древостоев восстановиться после сильнейшей засухи 2009-2010 гг. Выделим некоторые значимые особенности радиального приро- 
Таблица 7. Осредненные относительные индексы ( \%) радиального прироста деревьев сосны, растущих в насаждениях, находящихся на разных стадиях рекреационной дигрессии

\begin{tabular}{lccccccccc}
\hline \multirow{2}{*}{$\begin{array}{c}\text { Район } \\
\text { исследований }\end{array}$} & \multirow{2}{*}{ N. ПП } & Стадия & \multicolumn{7}{c}{ Годы } \\
\cline { 4 - 10 } & & дигрессии & 2007 & 2008 & 2009 & 2010 & 2011 & 2012 & 2013 \\
\hline Урочище & 3 & I & 113 & 123 & 119 & 77 & 65 & 54 & 75 \\
«Маклок» & 2 & II & 128 & 154 & 107 & 64 & 49 & 55 & 61 \\
& 1 & II-III & 119 & 132 & 95 & 62 & 44 & 44 & 41 \\
Урочище & 4 & III-IV & 123 & 137 & 108 & 83 & 61 & 61 & 49 \\
«Боровое» & 5 & IV & 140 & 139 & 103 & 72 & 63 & 55 & 47 \\
\hline
\end{tabular}



Рис. 2. Динамика ширины годичных колец деревьев сосны, растущих в насаждениях, находящихся на разной стадии рекреационной дигрессии (урочище «Маклок» и урочище «Боровое»)

ста сосны на разных стадиях рекреационной дигрессии за период 2004-2013 гг::

- на всех стадиях дигрессии в 2008 г. прирост увеличился;

- на всех стадиях дигрессии прирост уменьшался в 2009-2011 гг;

- в 2009 и 2010 гг. на всех стадиях дигрессии есть одно-два дерева, не уменьшающие прирост (причем это разные деревья в 2009 и 2010 гг.);

- в 2012 г. средний прирост увеличился на II стадии дигрессии, а в 2013 г. - на I и II стадиях дигрессии. На III и IV стадиях дигрессии он продолжает падать;
- на IV стадии дигрессии не менее половины деревьев, вероятнее всего, погибнут (усохнут), два из них уже не дали прироста в 2013 г.

Анализ графиков радиального прироста показал, что на всех пробных площадях даты экстремумов прироста в основном совпадают (рис. 2). Начиная с 1970-х гг. (т.е. после прохождения этапа интенсивного снижения прироста, характерного для молодняков) на стадии дигрессии, переходной от II к III, наблюдаем несколько более высокую амплитуду колебаний прироста, особенно с конца 1980-х. Наиболее равномерная амплитуда колебаний на I стадии дигрессии. 
Анализируя прирост по стадиям дигрессии II-III, III-IV и IV (рис. 2), в двух урочищах мы видим еще более высокую амплитуду колебаний на стадии дигрессии III-IV, но на IV стадии дигрессии снижается амплитуда и очень значительно нарушается цикличность прироста. С середины 1990-х гг. цикличность прироста как на IV, так и на III-IV стадиях дигрессии сглаживается.

Следует отметить, что плавность колебаний прироста - одна из важнейших характеристик устойчивости, жизнеспособности древостоя, как и равномерная, без резких перепадов, амплитуда колебаний прироста.

При анализе графика прироста на I, IIIII и IV стадиях дигрессии с 1980-х гг. подтверждаются выявленные тенденции: на I стадии прирост имеет равномерную амплитуду колебаний и четко выраженную цикличность. На стадии дигрессии II-III амплитуда колебаний более высокая, а на IV стадии дигрессии сильно нарушена цикличность прироста (рис. 2).

Анализ циклической динамики солнечной активности и ГТК Селянинова за май-сентябрь показывает наличие сходных экстремумов в 11-летнем цикле солнечной активности с отклонением $\pm 2-3$ года (рис. 3 ).

Корреляция суммы осадков (Р) (апрельсентябрь) с ГТК (май-сентябрь) составляет 0,92-0,93. Это естественно, так как ГТК рассчитывается по сумме осадков и сумме температур, а осадки в лесостепи служат основным лимитирующим фактором.

При рассмотрении характера корреляционных связей индексов прироста (I) с солнечной активностью, выраженной в числах Вольфа (W), ГТК и осадками (P), достоверной связи с солнечной активностью не обнаруживается (табл. 8). Характер связей прироста деревьев с солнечной активностью сложен, постепенно меняется с течением времени, что является следствием смены фаз активности Солнца в различных по длительности циклах и, вероятно, с другими, пока ещё не известными нам факторами.

Достоверная слабая корреляция индексов прироста (I) наблюдается с ГТК и с осадками теплого периода. В древостое, находящемся на IV стадии рекреационной дигрессии, связь c климатическими факторами фактически полностью отсутствует. Очевидно, что имен-

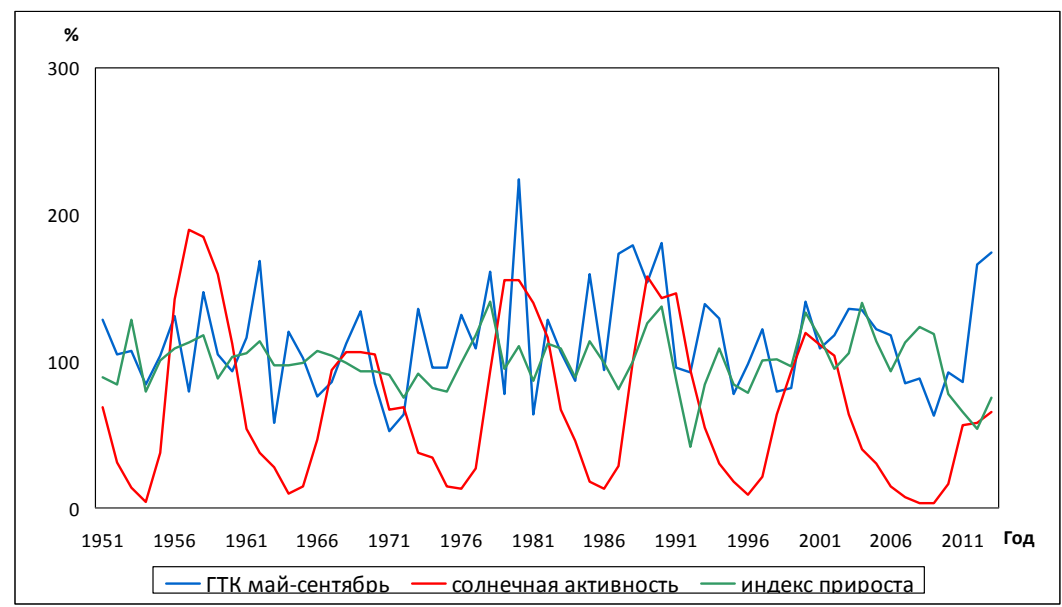

Рис. 3. Динамика индексов прироста сосны обыкновенной (урочище «Маклок», I стадия дигрессии), гидротермического коэффициента Селянинова (ГТК) и солнечной активности (чисел Вольфа) 
Таблица 8. Коэффициенты корреляции индексов прироста деревьев сосны, растущих в насаждениях, находящихся на разной стадии рекреационной дигрессии, с лимитирующими факторами (временной интервал составляет 48 лет)

\begin{tabular}{cccc}
\hline Стадия дигрессии & ГТК, \% & Р, мм & W \\
\hline I & 0,25 & 0,17 & 0,13 \\
II & 0,31 & 0,24 & 0,13 \\
II-III & 0,22 & 0,17 & 0,11 \\
III-IV & 0,26 & 0,17 & 0,07 \\
IV & 0,03 & $-0,06$ & $-0,07$ \\
\hline
\end{tabular}

Примечание: W - числа Вольфа, Р - атмосферные осадки (апрель-сентябрь), ГТК - гидротермический коэффициент Селянинова (май-сентябрь)

Таблица 9. Результаты кластерного анализа значений радиального прироста сосны и лимитирующих факторов по годам

\begin{tabular}{cllll}
\hline \multirow{2}{*}{ Кластер } & \multicolumn{4}{c}{ Средние значения (диапазон средних) } \\
\cline { 2 - 5 } & \multicolumn{1}{c}{ ГТК, \% } & \multicolumn{1}{c}{ Р, мм } & \multicolumn{1}{c}{$\mathrm{I}, \%$} \\
\hline 1 & $132,9(105,0-168,0)$ & $361,3(300,0-431,0)$ & $40,7(18,0-69,0)$ & $104,2(84,0-139,9)$ \\
2 & $101,6(78,0-132,0)$ & $306,3(266,0-338,0)$ & $20,1(2,9-104,0)$ & $97,7(77,3-128,4)$ \\
3 & $97,4(64,0-134,0)$ & $296,9(236,0-342,0)$ & $126,8(67,0-190,0)$ & $98,3(86,8-113,2)$ \\
4 & $75,9(52,0-96,0)$ & $236,6(158,0-280,0)$ & $54,7(3,1-94,0)$ & $87,7(42,0-118,7)$ \\
5 & $145,9(109,0-181,0)$ & $418,1(384,0-487,0)$ & $132,14(93,0-185,0)$ & $126,2(111,7-140,9)$ \\
6 & $183,2(166,0-224,0)$ & $521,6(469,0-563,0)$ & $81,4(29,0-55,0)$ & $84,1(54,0-110,3)$ \\
\hline
\end{tabular}

Примечание: ГТК - гидротермический коэффициент Селянинова (май-сентябрь), Р - осадки (апрель-сентябрь), $\mathrm{W}$ - числа Вольфа, I - индексы радиального прироста сосны

но IV стадия дигрессии является переходом древостоя к необратимой фазе ухудшения состояния, что подтверждается характером изменений и других компонентов лесного фитоценоза.

Следует отметить в целом низкие значения прямолинейной корреляции индексов прироста искусственных сосновых древостоев пригородной зоны с климатическими факторами.

Результатом кластерного анализа (метод Варда) значений прироста и лимитирующих факторов по календарным годам (рис. 4) стал лишь вывод, подтверждающий результаты наших более ранних исследований (Матвеев, 2003) другими методами (метод наложенных эпох и др.): наиболее высокая связь приро- ста, солнечной активности (в числах Вольфа), осадков и ГТК наблюдается в Центральной лесостепи на ветви роста солнечной активности, второй максимум (несколько меньший) на ветви спада (табл. 9).

\section{Заключение}

Лесоводственное и дендроклиматическое исследование насаждений сосны обыкновенной, подверженных рекреационной дигрессии разной интенсивности в пригородной зоне г. Воронежа, позволило установить следующее. С увеличением рекреационной нагрузки до достижения IV стадии дигрессии состояние насаждений резко ухудшается. Эти древостои значительно сильнее пострадали от засухи 2010 г. Усыхание отдельных 


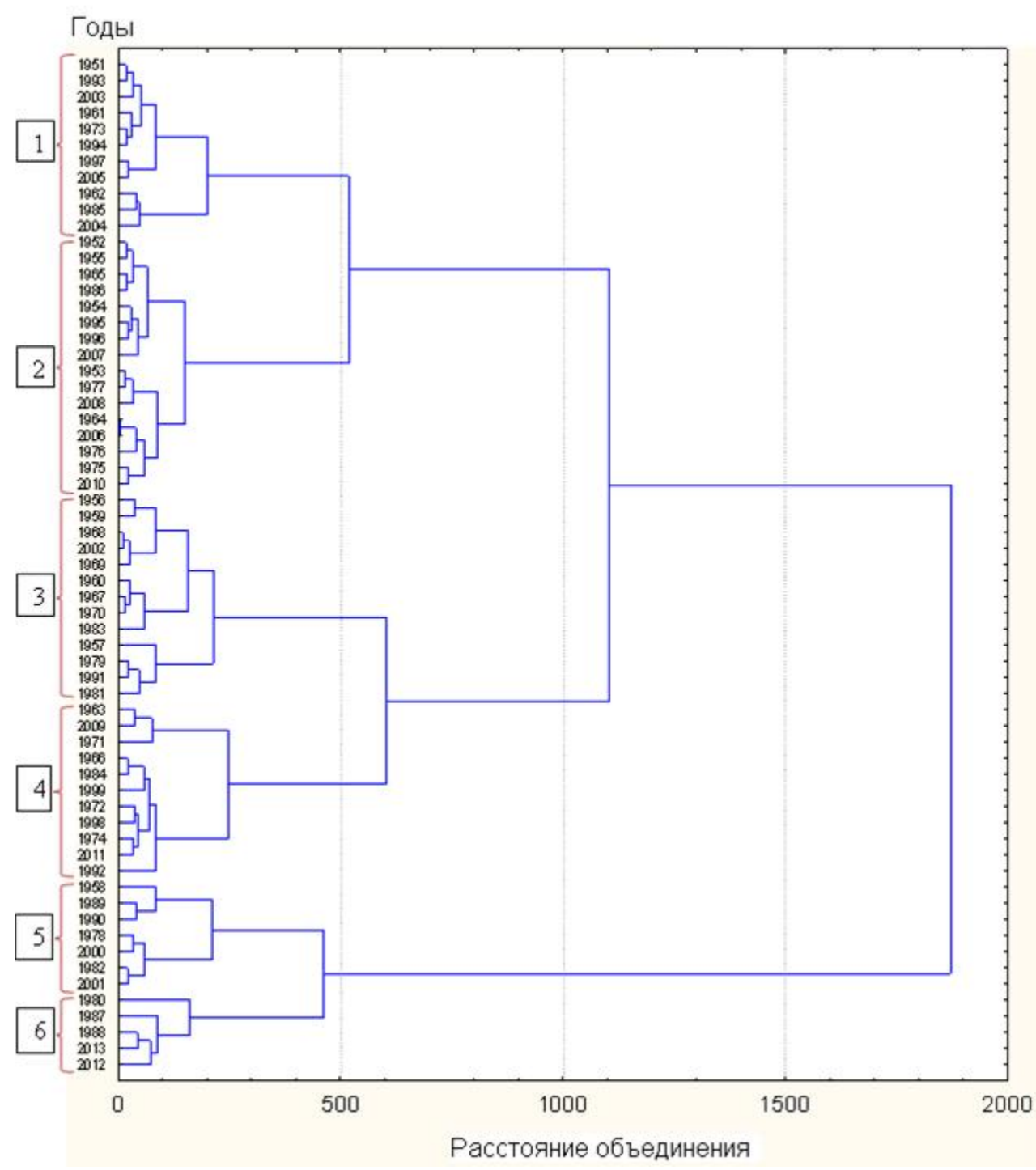

Рис. 4. Результаты кластерного анализа (метод Варда) радиального прироста деревьев и лимитирующих факторов (гидротермический коэффициент Селянинова (май-сентябрь), сумма осадков теплого периода (апрель-сентябрь), числа Вольфа) по календарным годам (для 63 наблюдений)

деревьев продолжается во всех искусственных древостоях сосны до настоящего времени независимо от стадии дигрессии. В годы после сильных засух увеличиваются до максимальных значений (>60\%) коэффициенты изменчивости радиального прироста, особенно сильно (до 104 \%) - на IV стадии дигрессии.

\section{Исследование выполнено при поддержке Российского научного фонда (проект} № 14-17-00171). 


\section{Список литературы}

Битвинкас Т.Т. (1974) Дендроклиматические исследования. Л., Гидрометеоиздат, 170 с. [Bitvinkas T.T. (1974) Dendroclimatic study. L.: Gidrometeoizdat, 170 p. (in Russian)]

Ваганов Е.А., Шиятов С.Г., Мазепа В.С. (1996) Дендроклиматические исследования в Урало-Сибирской Субарктике. Новосибирск, Наука, 246 с. [Vaganov E.A., Shiiatov S.G., Mazepa V.S. (1996) Dendroclimatic studies in the Ural-Siberian Subarctic Zone. Novosibirsk, Nauka, 246 p. (in Russian)]

Вахнина И.Л. (2011) Радиальный прирост сосны обыкновенной (Pinus sylvestris L.) в зеленой зоне города Читы во второй половине прошлого столетия. География и природные ресурсы, 1: 180-182 [Vakhnina I.L. (2011) Radial growth of Scots pine (Pinus sylvestris L.) in the green zone of Chita in the second half of the last century. Geography and natural resources [Geografiia i prirodnye resursy], 1: 180-182 (in Russian)]

Вересин М.М. (1971) Леса Воронежские. Происхождение, облик и будущее наших лесных ландшафтов. М: Центрально-Черноземное книжное издательство, 224 с. [Veresin M.M. (1971) Voronezh Forests. Origin, habitus and future of our forest landscapes. Moscow, Central Black Earth Book Publishing House, 224 p. (in Russian)]

Казанская Н.С., Ланина В.В., Марфенин Н.Н. (1977) Рекреационные леса. М., Лесная промышленность, 96 с. [Kazanskaia N.S., Lanina V.V., Marfenin N.N. (1977) Recreational Forests. Moscow, Forest Industry, 96 p. (in Russian)]

Колчин Б.А., Черных Н.Б. (1977) Дендрохронология Восточной Европы. М., Наука, 128 с. [Kolchin B.A., Chernykh N.B. (1977) Dendrochronology of Eastern Europe. Moscow, Nauka, 128 p. (in Russian)]

Костин С.И. (1965) Связь колебаний прироста деревьев с солнечной активностью. Лесное хозяйство, 4: 12-14 [Kostin S.I. (1965) Connection of tree growth fluctuations with solar activity. Forestry [Lesnoe khoziaistvo], 4: 12-14 (in Russian)]

Ловелиус Н.В. (1979) Изменчивость прироста деревьев. Дендроиндикаџия природных процессов и антропогенных воздействий. Л., Наука, 232 с. [Lovelius N.V. (1979) Variability of tree growth. Dendroindication of natural processes and anthropogenic influences. Leningrad, Nauka, 232 p. (in Russian)]

Матвеев С.М. (2003) Дендроиндикачия динамики состояния сосновых насаждений Центральной лесостепи. Воронеж, Изд-во ВГУ, 272 с. [Matveev S.M. (2003) Dendroindication of dynamics of pinery in the Central forest-steppe. Voronezh State University, 272 p. (in Russian)]

Матвеев C.M. (2005) Динамика состояния сосновых насаждений под воздействием рекреации. Вестник ВГУ. География и геоэкология, 2: 97 - 103 [Matveev S.M. (2005) The dynamics of pinery under the influence of recreation. Bulletin of Voronezh State University. Geography and geoecology [Vestnik VGU. Geografiia i geoekologiia], 2: 97-103 (in Russian)]

Матвеев C.M. (2006) Методика дендрохронологического анализа. Методические указания к лабораторным работам по дендрохронологии для студентов специальности 250201 - Лесное хозяйство дневной и заочной форм обучения. Воронеж, 39 с. [Matveev S.M. (2006) Methods of the dendrochronological analysis. Methodical instructions to laboratory works on dendrochronology for students majoring in Forestry (250201) of full-time and part-time forms of education. Voronezh, 39 p. (in Russian)] 
Мироненко А.В., Матвеев С.М. (2012) Свидетельство о государственной регистрации программы ЭВМ № 2012613667 «Программа расчета тренда временных рядов и индексированных значений с исключением тренда». Заявка № 2012611206. [Mironenko A.V., Matveev S.M. (2012) Certificate of state registration of a computer program No. 2012613667 "A program for calculation of the time-series trend and indexed values with the exception of the trend". Application No. 2012611206 (in Russian)]

Никитченко Л.А., Миленин А.И. (2012) Мониторинг рекреационного воздействия на Пригородные леса города Воронеж. Лесотехнический журнал, 4 (8): 167-171 [Nikitchenko L.A., Milenin A.I. (2012) Monitoring the recreation impact on the Suburban Forests of Voronezh. Journal of Forestry [Lesotekhnicheskii zhurnal], 4 (8): 167-171 (In Russian)]

Николаевский В.С. (1983) Система фитоиндикаџии загрязнения воздуха и состояния лесной растительности: сб. науч. тр. Гомель, с. 379-381 [Nikolaevskii V.S. (1983) The phytoindication system of air pollution and the state of the forest vegetation. Collection of scientific works. Gomel, $\mathrm{p}$. 379-381 (in Russian)]

Погода и климат - Климат Воронежа (2013) [Weather and Climate - The climate of Voronezh (2013) / http://www.pogoda.ru.net/climate/34123 (in Russian)]

Рыгалова Н.В. (2014) Изучение локальных особенностей радиального прироста сосны обыкновенной Касмалинского и Барнаульского ленточных боров методом пунктирной трансекты. Известия Алтайского государственного университета, 3-1 (83): 78-83 [Rygalova N.V. (2014) The study of local features of radial growth of Scots pine in Kasmalinsk and Barnaul ribbon pine forests by a transect method. Proceedings of Altai State University [Izvestiia AGU], 3-1 (83): 7883 (in Russian)]

Рысин Л.П., Рысин С.Л. (2008) Природные и социальные аспекты рекреационного использования лесов. Лесохозяйственная информаиия, 6-7: 37 - 51 [Rysin L.P., Rysin S.L. (2008) Natural and social aspects of recreational use of forests. Forestry information [Lesokhoziaistvennaia informatsiia], 6-7: 37-51 (in Russian)]

Санитарные правила в лесах Российской Федеращии (1998) М., 25 с. [Sanitary rules in forests of the Russian Federation (1998), Moscow, 25 p. (in Russian)]

Скрябин М.П. (1946) Вековые циклы природных условий и боровая лесная растительность лесостепи. Материалы по изучению причин усыхания дуба в лесостепной зоне: Труды Воронежского государственного заповедника. Вып. 3. М., с. 89-108 [Scriabin M.P. (1946) Secular cycles of natural conditions and pine forest vegetation of the forest-steppe. Proceedings of the study of causes of oak drying in the forest-steppe zone: Proceedings of the Voronezh State national Park. V. 3. Moscow, p. 89-108 (in Russian)]

Таранков В.И. (1993) Влияние климатических и антропогенных факторов на состояние и продуктивность сосновых насаждений зеленой зоны г. Воронежа. Сосновые леса России в системе многоиелевого лесопользования. Тез. Всерос. конф. Воронеж, с. 94-96 [Tarankov V.I. (1993) Influence of climatic and anthropogenic factors on the state and productivity of pinery in the Green Zone of Voronezh. Pine forests in Russia in the system of multi-purpose forest management. Proceedings of the All-Russian Conference in Voronezh, p. 94-96 (in Russian)]

Тимащук Д.А. (2012) Дендроиндикация рекреационной дигрессии сосновых насаждений в Усманском бору Воронежской области. Воспроизводство, мониторинг и охрана природных, 
природно-антропогенных и антропогенных ландшафтов. Материалы международной молодежной научной школы 14-15 июня 2012 г. Воронеж, ВГЛТА, с. 272-276 [Timashchuk D.A. (2012) Dendroindication of recreational digression of pinery in the Usman forest of Voronezh region. Reproduction, monitoring and protection of natural and man-made landscapes. Proceedings of the International Youth Scientific School held on June 14-15, 2012. Voronezh State Forest Technical Academy, p. 272-276 (in Russian)]

Тимофеев А.В. (2008) Специфика действия засух на рост сосны обыкновенной (Pinus sylvestris L.) в лесопарках и пригородных лесах Тольятти. Самарская Лука, 17 (4(26): 902-908 [Timofeev A.V. (2008) Specificity of drought influence on growth of Scots pine (Pinus sylvestris L.) in forest parks and suburban forests in Tolyatti. Samara bend [Samarskaia Luka], 17 (4 (26): 902-908 (in Russian)]

Шведов Ф.Н. (1892) Дерево как летопись засух. Метеорологический вестник, 5: 163-178 [Shvedov F.N. (1892) A tree as a drought record. Meteorological Herald [Meteorologicheskii vestnik], 5: 163-178 (in Russian)]

Шиятов С.Г. (1973) Дендрохронология, ее принципы и методы. Зап. Свердл. отд-ния ВБО. Вып. 6. Свердловск, с. 53-81 [Shiiatov S.G. (1973) Dendrochronology, its principles and methods. Proceedings of VBO Sverdlovsk Department. V. 6. Sverdlovsk, p. 53-81 (in Russian)]

Шиятов С.Г. (1986) Дендрохронология верхней граниџы леса на Урале. М., Наука, 136 с. [Shiiatov S.G. (1986) Dendrochronology of the upper forest border in the Urals. Moscow, Nauka, 136 p. (in Russian)]

Douglass A.E. (1919) A study of the annual rings of trees in relation to climate and solar activity. Climatic cycles and tree-growth. V. 1. Washington, Carnegie Inst., 127 p.

Solar Influences Data analysis Center (2013)/ http://sidc.oma.be/sunspot-data/ 